\title{
POESIAS
}

Luís Alberto Cinquarole Bellíssimo

\section{Análise morfossintática}

Eu amo você

oração

em que o eu

sujeito

ao objeto

direto ama

$\mathrm{O}$ amor transita no verbo

diretamente

e se faz carne

então sujeito e objeto

se confundem se fundem se com

em um período simples

e ora são

absoluta unidade

Não há adjuntos

Estrutura profunda à flor da frase

espinho e flor num fluxo de sangue

fixam o sentido

$\mathrm{Na}$ relação das formas

a função foge ao senso

e sujeito e objeto verbalizam

juras

Numa troca de posição e fluido

claro, a pre-

posição se estabelece

a você eu amo

Eu amo você

eu, sempre sujeito e representação da figuração

o ego, o consciente

que assim se revela e não se conhece

mas se reconhece enquanto tal

pessoal e reto

pronome, pró-figuração da substância que está sob 
e sobre porque real

aquele que fala em nome de

e que se explica por proposições

pronominais

— o si mesmo -

e assim se terceiriza, embora

no discurso, seja a primeira pessoa

o ser por excelência, que se opõe ao outro

aos outros

- o ser:

nominalização do verbo

carne que se faz

essência, mas

que existe na oração

"Eu amo você"

porque ama e não pensa

Pensar é abstrair-se da existência

anticartesianamente

Você, pronome, a terceira

pessoa à mercê da segunda e, aqui

objeto da primeira

em direção à qual se lança a seta

direta do sujeito de amar

já flechado

pronome objeto, reto

que não poderia obliquamente se deslocar

para antes do verbo

como um mero te, a não ser

artificialmente

regido por uma preposição, um $a$

direcional

que distanciaria o sujeito

- um eu platonicamente concertado com as sombras

frente ao você ideal

Eu amo você

e você se pluraliza em favores

e em ti vos amo

eu, mercê, sujeito ao objeto

direto amo

verbo que, na primeira conjugação

se flexiona em todos

os tempos e modos e aspectos e pessoas e

podendo ser numericamente plural

é singular 
e transitivo e transitório, embora

infinito enquanto dure o amor ou o amante

mas aqui presente: amo

e o amor transita da primeira pessoa

em transe

diretamente a você

permansivamente

sem, contudo, que o verbo se terceirize

(a recíproca pode ser admitida, mas não cabe na análise)

A simplicidade do sujeito se impõe

ao que já foi dito

amo você

predicado verbalizado

que não pode ser logicamente demonstrado

a não ser figurativamente

Eu amo você

oração absoluta

por uma graça imerecida

contudo

vida

\section{FAX}

Você digita.

A campainha encampa a noite

sobrepujando os ais

eco do corvo Poe

mático

defendo o silêncio

auto

"Alô!"

Você se imprime na noite

vaga-

rosa

cor

vo

látil da antemanhã. 


\section{PALANQUE}

Fala sem cio

fala ácida

falácia..

\section{REBELDIA}

Meu destino ninguém traça

Se não dito o rumo

sumo

e o deito às traças

\section{ARANHA}

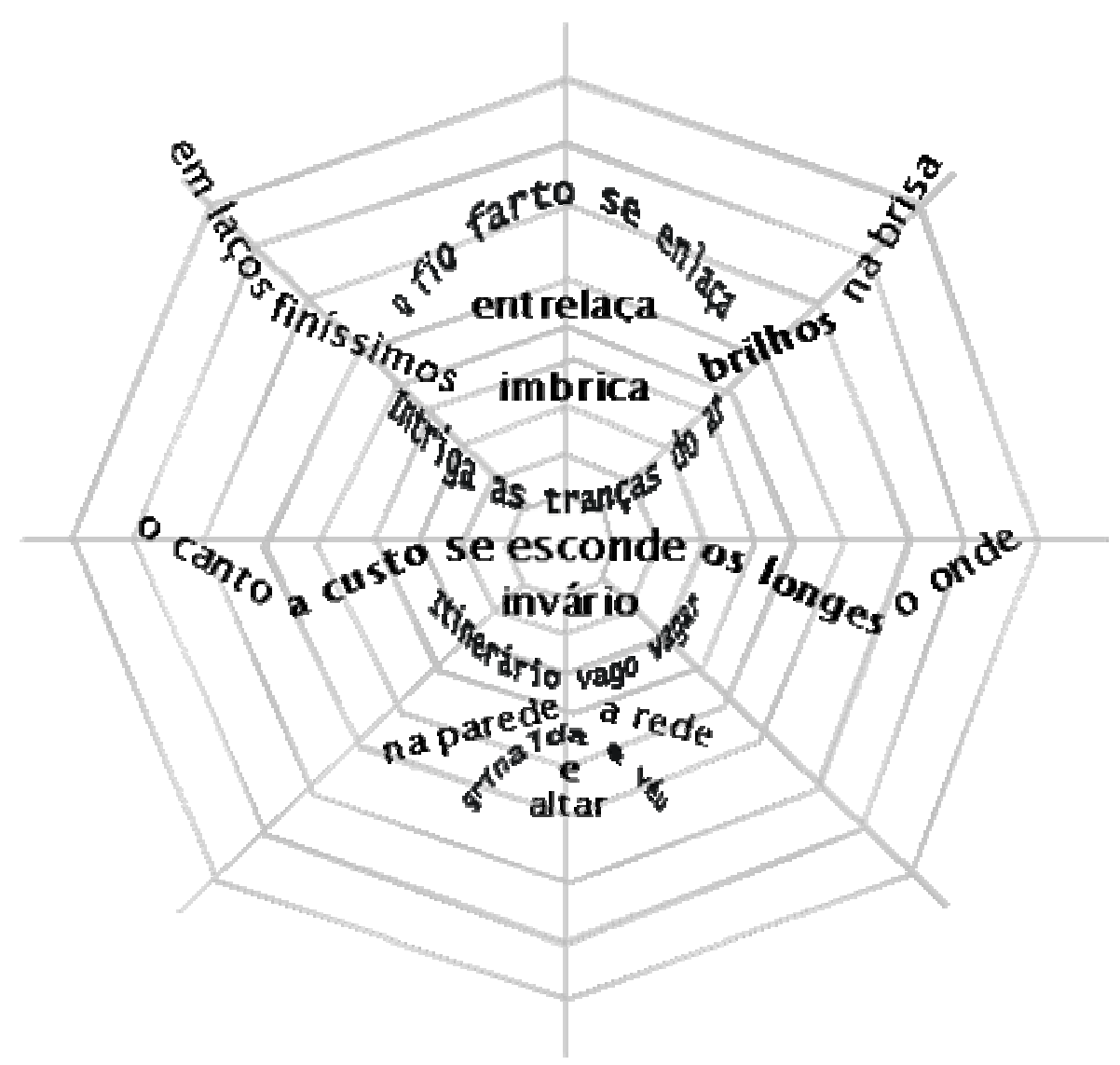




\section{FINADOS}

Os mortos se vestem para o feriado

em família

Há encontros comunitários

e todos se congraçam com a morte

anfitriã sem fronteiras

nem etiquetas

Homens e mulheres vestem os finados

no feriado

e dão vivas à inevitável

A vida sorri a essa rega ritual

e, enquanto a morte põe a regra aos vivos,

subverte os mortos

recompondo-os como elo

vital

\section{SOLO}

Sou o que penso que sou

Sou o que pensam que sou

$\mathrm{O}$ que não penso

o que não pensam

sou

Sou o que não sou

A vida é um paradoxo

Sou o que digo de mim em altos brados nos jardins

nos edifícios

Sou o que dizem de mim

em altos brados nas praças

nos muros

A vida é um outdoor

Sou o que de mim

meu silêncio diz

Sou o que diz o silêncio

dos outros em mim, de mim

A vida é um mistério

Sendo

sou o que sou

a vida 
"Après moi le déluge!"

\section{ARRANJO}

A vida vive em mim

Fora de mim a vida é

só eu constato

A vida vive

não quando penso

nem quando digo

mas quando ato

\section{ERRANTE}

a perda a pedra

um jogo de amarelinha

com palavras

em que o erre

se desloca

a pedra empecilho por acréscimo

ausência constatada a perda

a pedra esvazia os caminhos

a perda avoluma o vazio

um jogo de amar

e linha em que o erro se desloca

pedra a tua perda

erra meus olhos plenos do caminho

vazio 